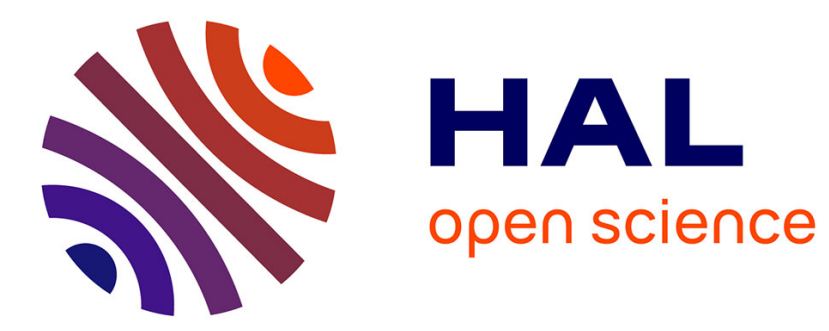

\title{
The missing stase in spider mites (Acari: Tetranychidae): when the adult is not the imago.
}

H.M. André, G. van Impe

\section{To cite this version:}

H.M. André, G. van Impe. The missing stase in spider mites (Acari: Tetranychidae): when the adult is not the imago.. Acarologia, 2012, 52 (1), pp.3-16. 10.1051/acarologia/20122038 . hal-01566511

\section{HAL Id: hal-01566511 \\ https://hal.science/hal-01566511}

Submitted on 21 Jul 2017

HAL is a multi-disciplinary open access archive for the deposit and dissemination of scientific research documents, whether they are published or not. The documents may come from teaching and research institutions in France or abroad, or from public or private research centers.
L'archive ouverte pluridisciplinaire $\mathbf{H A L}$, est destinée au dépôt et à la diffusion de documents scientifiques de niveau recherche, publiés ou non, émanant des établissements d'enseignement et de recherche français ou étrangers, des laboratoires publics ou privés.

\section{(ㅇ)(1) $\$$}

Distributed under a Creative Commons Attribution - NonCommercial - NoDerivatives| 4.0 


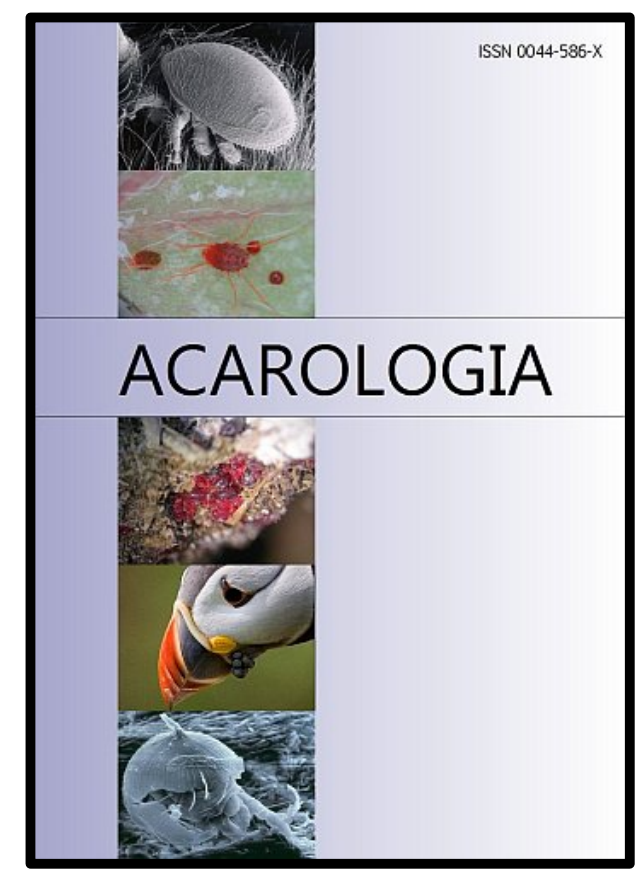

\section{ACAROLOGIA}

A quarterly journal of acarology, since 1959

Publishing on all aspects of the Acari

All information:

http://www1.montpellier.inra.fr/CBGP/acarologia/ acarologia@supagro.inra.fr

\section{OPEN ACCESS}

\section{Acarologia is proudly non-profit, with no page charges and free open access}

Please help us maintain this system by encouraging your institutes to subscribe to the print version of the journal and by sending us your high quality research on the Acari.

Subscriptions: Year 2017 (Volume 57): $380 €$ http://www1.montpellier.inra.fr/CBGP/acarologia/subscribe.php

Previous volumes (2010-2015): $250 € /$ year (4 issues)

Acarologia, CBGP, CS 30016, 34988 MONTFERRIER-sur-LEZ Cedex, France

The digitalization of Acarologia papers prior to 2000 was supported by Agropolis Fondation under the reference ID 1500-024 through the « Investissements d'avenir » programme

(Labex Agro: ANR-10-LABX-0001-01)
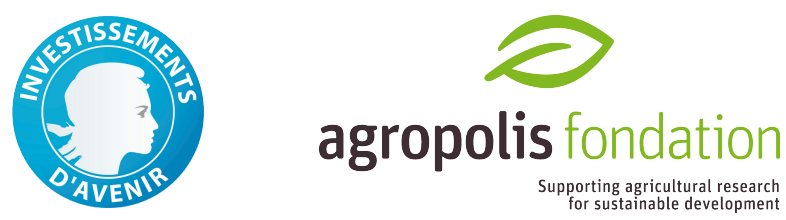

Acarologia is under free license and distributed under the terms of the

Creative Commons-BY-NC-ND which permits unrestricted non-commercial use, distribution, and reproduction in any medium, provided the original author and source are credited. 


\title{
THE MISSING STASE IN SPIDER MITES (ACARI: TETRANYCHIDAE): WHEN THE ADULT IS NOT THE IMAGO
}

\author{
Henri M. ANDRÉ ${ }^{1,2}$ and Georges VAN IMPE ${ }^{2}$ \\ (Received 10 August 2011; accepted 10 February 2012; published online 30 March 2012) \\ ${ }^{1}$ Invertébrés non-Insectes, Department of Zoology, Musée royal de l'Afrique centrale, B-3080 Tervuren, Belgium. hmandre@bluewin.ch \\ ${ }^{2}$ Centre de recherche sur la biodiversité, Earth and Life Institute, Université Catholique de Louvain, Place Croix du Sud 5, \\ B-1348 Louvain-la-Neuve, Belgium.georges.vanimpe@skynet.be
}

\begin{abstract}
Apart from a calyptostatic prelarva, the ontogeny of spider mites is limited to one six-legged immature followed by three eight-legged instars. The usage consists in naming them: larva, protonymph, deutonymph and adult. In this study, the "missing stase" and different associated hypotheses are explored using diverse approaches: light microscopy, electron microscopy, comparative chaetotaxy, ontogenetic trajectories, and interspecific comparisons. It turns out that the imago (new name for the last stase) is missing in Tetranychus urticae and that its post-embryonic development may be summarized as follows: prelarva (calyptostase), larva (six-legged stase), protonymph (eight-legged stase), deutonymph (eight-legged stase), tritonymph (with paedogenesis, i.e. precocious development of sexual maturity). The respiratory role of the prelarva is emphasized. The current terminology of post-embryonic development is confusing as it pertains to three approaches: the state or form description, the instar standard and the stase paradigm.
\end{abstract}

KEYWORDS - Tetranychus urticae; ontogeny; ontogenetic trajectory; paedogenesis; stase; state; instar; respiration

\section{INTRODUCTION}

Aside from ticks, Tetranychidae are the most studied mites; a huge amount of literature is devoted to their biology (see Helle and Sabelis, 1985) and they have been proposed as a chelicerate model organism (Grbić et al., 2007). The ontogeny of spider mites is noteworthy in that it comprises only four active stases. Surprisingly, no attempt has been made to elucidate the true identity of these active stases or to demonstrate that the so-called "missing" stase was really missing or merely calyptostatic.

Apart from a calyptostatic prelarva described by Grandjean (1948), the ontogeny of spider mites includes one six-legged immature followed by three eight-legged instars. The usage consists in naming them: larva, protonymph, deutonymph and adult. These names imply that the "missing stase" is the tritonymph. Yet, any stase is likely to be "missing" or, at least, to be calyptostatic. These names also imply that the first eight-legged instar is homologous to the protonymph of other actinotrichid mites with five active stases. This has not been demonstrated and it is not by chance that Grandjean (1948) used the expressions larva, first and second nymphs instead of the prevailing appellations. Let's designate this usual interpretation, the null hypothesis, $\mathrm{H}_{\mathrm{o}}$ (Fig. 1B).

A priori, three alternative hypotheses may be advanced. The first hypothesis, $\mathrm{H}_{\mathrm{m}}$, is a multiple 


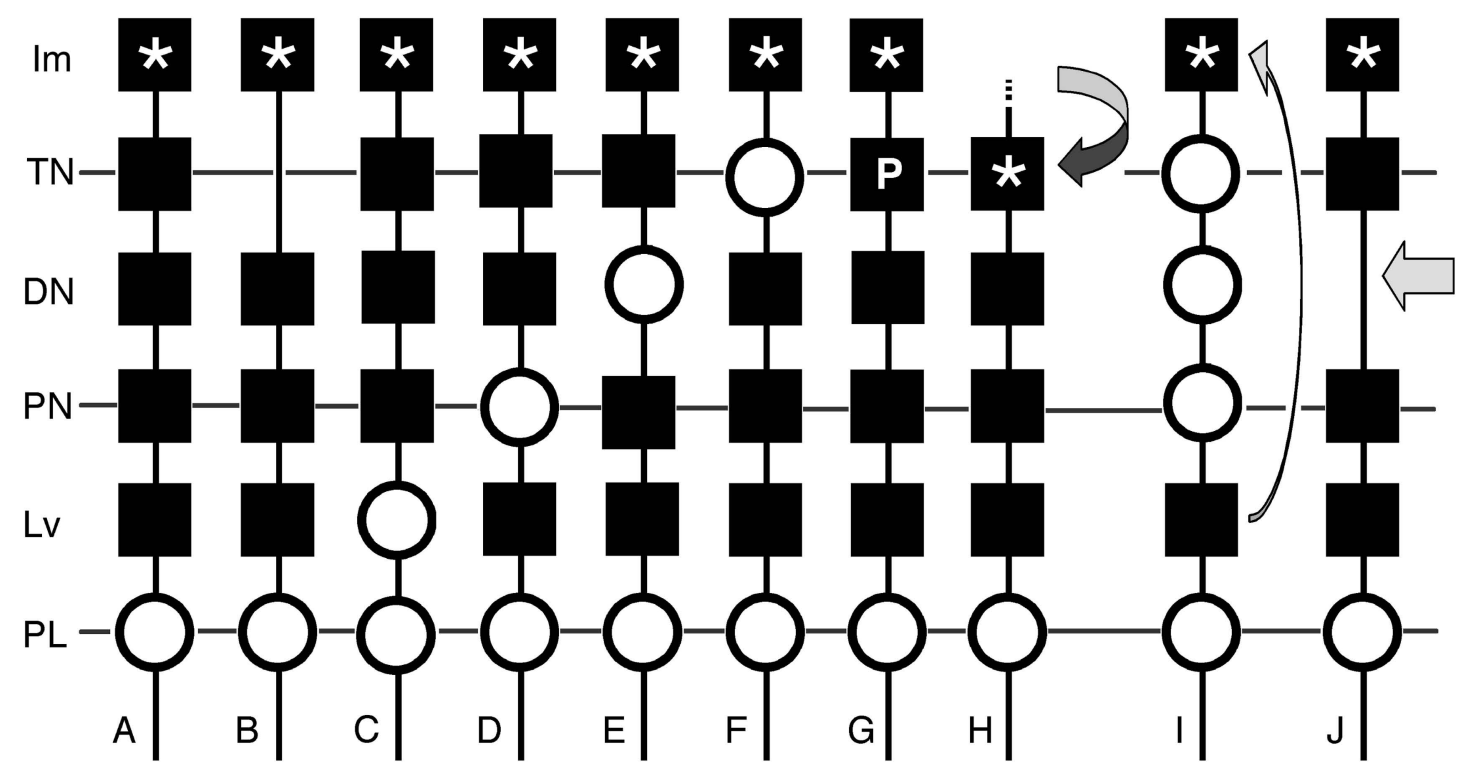

FIgURE 1: Ontogeny in Tetranychoidea $(\mathrm{A}-\mathrm{H})$ and other mites $(\mathrm{I}-\mathrm{J})$. A - Plesiomorphic ontogeny observed in Tuckerellidae; B Tetranychidae (traditional interpretation - hypothesis $\mathrm{H}_{\mathrm{o}}$ ); $\mathrm{C}-$ multiple protelattosis in Tetranychidae (hypothesis $\mathrm{H}_{\mathrm{m}}$ ); D-E-F metelattosis in Tetranychidae (intervening calyptostasis, hypothesis $\mathrm{H}_{\mathrm{i}}$ ); $\mathrm{G}$ - Tuckerellidae with a paedomorphic tritonymph; $\mathrm{H}$ progenesis in Tetranychidae (hypothesis $\mathrm{H}_{\mathrm{p}}$ ); I - three calyptostasic nymphs in Ereynetidae (Speleognathinae); $\mathrm{J}$ - only four active stases in Astigmata (Psoroptidae). Im: imago; TN: tritonymph; DN: deutonymph; PN: protonymph; Lv: larva; PL: prelarva. Close square: active homostase; Open circle: calyptostase; P: paedomorphic tritonymph; *: reproductive system.

protelattosis (Fig. 1C). Protelattosis, i.e. the occurrence of a calyptostase at the beginning of ontogeny (Hammen, 1975, 1980), is widespread in Arachnida (André and Jocqué, 1986). In Tetranychidae, as in most Actinotrichida, the prelarva is calyptostatic and remains within the egg (Grandjean, 1948). Multiple protelattosis involves the succession of several calyptostases at the beginning of the ontogeny. In Tetranychidae, this hypothesis implies that both the prelarva and the larva would be calyptostatic as already hypothesized in Myobiidae (Grandjean, 1938a). Some larvae tend to be weak, sluggish, nonfeeding forms (Walter and Krantz, 2009). As a result, the first active stase would be a six-legged protonymph. Strictly speaking, the presence of only six legs in a stase does not suffice to identify a larva and Grandjean (1938b: 1349) already deplored that acarologists were used to designate as larva any stase with six legs.

The second hypothesis, $\mathrm{H}_{\mathrm{i}}$, is metelattosis sensu Hammen $(1975,1980)$, which supposes the presence of a calyptostase intervening between two active stases in the course of ontogeny (Fig. 1D,E,F). Such calyptostases are detectable through the presence of an apoderm or other reduced organs. If the calyptostase is demonstrated to be the tritonymph (Fig. $1 F$ ), then $H_{i}$ is similar to $H_{o}$ as far as active stases are concerned; a major difference remains, however, that in the latter case, the tritonymph is really missing while, in the former, it is calyptostatic.

A third and last hypothesis, $\mathrm{H}_{\mathrm{p}}$, presupposes that the "missing stase" lies at the other end of the ontogeny and, in the absence of imago, implies that reproduction is taken over by the tritonymph, i.e. progenesis or paedogenesis (Fig. 1H).

To improve our understanding of the ontogeny of spider mites, we thus need to solve two problems. The first problem involves the identification of active stases. The second consists in checking whether the "missing stase" is really missing (meristasy) or reduced to a calyptostase (heterostasy). The first question may be addressed through comparative chaetotaxy and ontogenetic patterns. The second question, the detection of a calyptostase occurring somewhere in the ontogeny of spiders mites, requires careful examination of pharate mites or the 
use of electron microscopy techniques as suggested by André (1992).

\section{MATERIALS AND METHODS}

\section{Species}

Species used in comparative tests belong all to Actinotrichida (Table 1). Observations on Tetranychus urticae are also based on spider mites obtained from the permanent rearing of the ecology laboratory.

\section{Terminology}

There are four active stases in Tetranychidae. We number them from $S_{1}$ to $S_{4}$. Tuckerellidae have five active stases that may also be numbered, from $A_{1}$ to $A_{5}$. In contrast to Tetranychidae, an ontogenetic level may be assigned to tuckerellid stases, from $A_{1}$ corresponding to the larva to $A_{5}$ corresponding to the imago.

Apolysis is taken as the criterion to recognize the occurrence of a new stase as discussed by Hinton (1971, 1973, 1976), Coineau (1974) and Fink (1983). Pharate animals are thus designated by the name (or number) of the inner stase.

\section{Observation of the egg}

Due to the difficulties in preparing mite eggs for TEM studies, we did not reiterate embryological studies by Dittrich $(1968,1971)$ and Dittrich and Streibert (1969). All their observations were made at $24{ }^{\circ} \mathrm{C}$. As Dittrich was unaware of Grandjean's work (Dittrich, in litteris), we briefly re-interpret his observations at the light of the stase concept.

\section{Observation of pharate mites}

Pharate mites were prepared for transmission electron microscope (TEM) studies. Tetranychus urticae were fixed in glutaraldehyde and treated as in André and Remacle (1984).

\section{Comparative chaetotaxy}

Chaetotaxy of spider mites and its development have been studied by Wainstein (1958), Robaux and Gutierrez (1973) and Lindquist (1985). As ontogeny of chaetotaxy in Tuckerellidae, a tetranychoid family with five active stases, was described by QuirosGonzalez and Baker (1984), it is possible to carry out a comparative study of chaetotaxy of spider mites.

As homologies of leg chaetotaxy have not been fully determined on a comparative manner between Tetranychoidea (Lindquist, 1985), a quantitative approach was favored. For instance, the gain in setae on each leg segment may be compared between homologous stases of different mite families. Another quantitative approach is offered by the study of ontogenetic trajectories as explained hereafter.

\section{Ontogenetic trajectories}

The ontogenetic trajectory method (André, 1988) involves plotting points representing the stases in an $n$-dimensional character space and connecting the points representing the successive stases of a species. In this case, the stases were plotted in a

TABLE 1: Species used in quantitative analyses (Fig. 4).

\begin{tabular}{lll}
\hline Species & Classification & Reference \\
\hline Terpnacarus bouvieri & Endeostigmata Terpnacaroidea Terpnacaridae & Grandjean (1939) \\
Edbakerella marshalli & Prostigmata Tydeoidea Triophtydeidae & André (1980) \\
Pretriophtydeus tilbrooki & Prostigmata Tydeoidea Triophtydeidae & André (1980) \\
Tydeus spathulatus & Prostigmata Tydeoidea Tydeidae & André (1980, 2005) \\
Pronematus ubiquitus & Prostigmata Tydeoidea Iolinidae & André (1980) \\
Iolina nana & Prostigmata Tydeoidea Iolinidae & André (1984) \\
Tuckerella ornata & Prostigmata Tetranychoidea Tuckerellidae & Quiros-Gonzalez \& Baker (1984) \\
Tetranychus urticae & Prostigmata Tetranychoidea Tetranychidae & Vainshtein (1958), Robaux and Gutierrez (1973), Lindquist (1985) \\
\hline
\end{tabular}




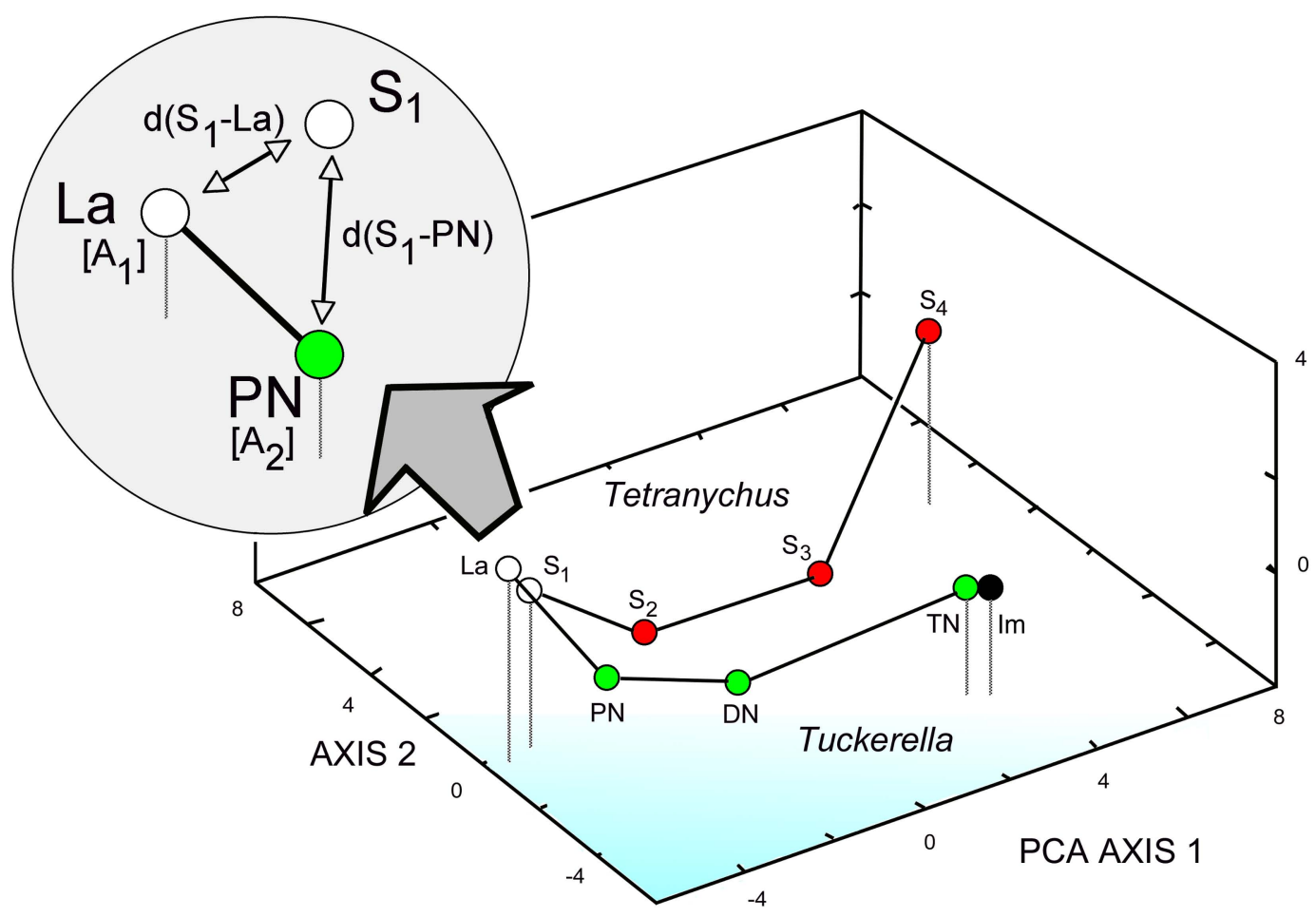

FIGURE 2: Ontogenetic trajectories of Tetranychidae and Tuckerellidae. Trajectories were plotted in a 27-dimensional space corresponding to chaetotaxy of leg segments, epimeral and genital chaetotaxy and, subsequently, projected into a 3-dimensional space through PCA. The insert describes the way distances are measured between homologous stases depending on the hypothesis chosen $\left(\mathrm{H}_{\mathrm{m}} \mathrm{vs}\right.$ $\left.\mathrm{H}_{\mathrm{p}}\right)$.

27-dimensional space, corresponding to the chaetotaxy of the 20 leg segments plus four axes describing the epimeral chaetotaxy and three for the genital formula (eugenital, aggenital, genital setae). Principal component analysis (PCA) was used to reduce these dimensions and project the 27-dimensional trajectories into a space of three dimensions. As the characters used are supposed to be discrete and independent, distances were estimated through the Manhattan metric (rather than Euclidian distance or Chebyshev distance) as made previously (e.g. André and Fain, 1991).

Distances may be measured in the character space between homologous stases belonging to different ontogenetic trajectories. Two sets of distances were measured corresponding to two different hypotheses. Either the first active stase of Tetranychidae, $S_{1}$, is supposed to be a larva as under the pae- dogenetic hypothesis, $\mathrm{H}_{\mathrm{p}}$; then the distance is measured between homologous stases, $i$, along all dimensions, $j$ :

$$
d\left(S_{i}-A_{i}\right)=\sum_{j=1-27}\left|S_{i}-A_{i}\right| \text { [see Fig. 2] }
$$

The mean distance between homologous stases is

$$
d=1 / 4 \sum_{i=1-4} d\left(S_{i}-A_{i}\right)
$$

Otherwise, if the first stase of Tetranychidae is homologized with a protonymph, i.e. with the second stase of Tuckerellidae as under the multiple protellatosis hypothesis, $\mathrm{H}_{\mathrm{m}}$, then:

$$
d\left(S_{i}-A_{i+1}\right)=\sum_{j=1-27}\left|S_{i}-A_{i+1}\right|[\text { see Fig. 2] }
$$

The mean distance between homologous stases is computed similarly. 


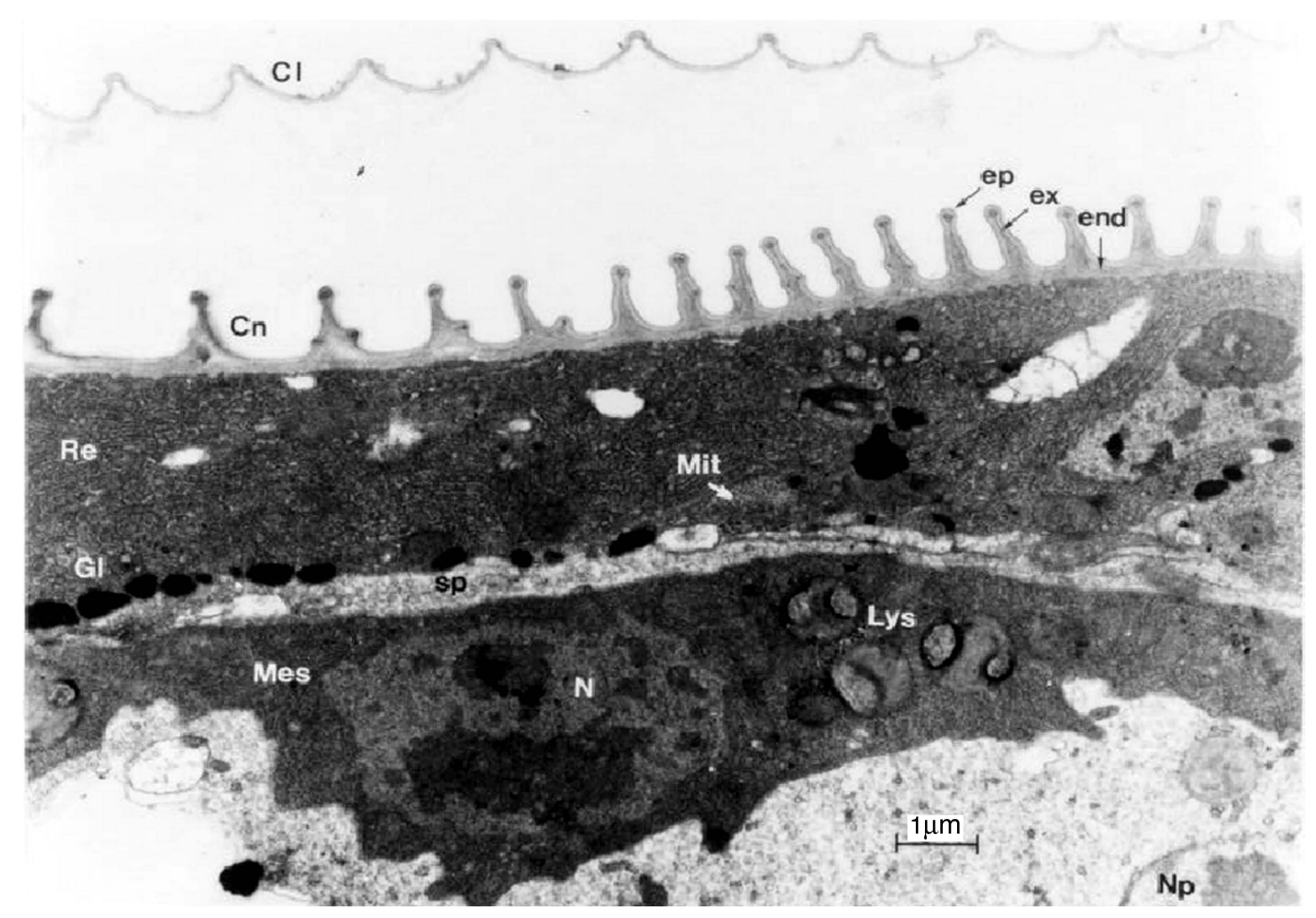

FIGURE 3: Tetranychus urticae, TEM of a pharate $S 1$ transforming into a S2. Abbreviations: $\mathrm{Cl}$ : $S 1$ cuticle; $\mathrm{Cn}$ : $S 2$ cuticle; en: endocuticle; epi: epicuticle; ex: exocuticle; GI: droplet of a not saturated lipid; Lys: lysosome; Mes: mesenchyme; Np: pycnotic nucleus of a lysed cell; Mit: mitochondria; N: nucleus; Re: endoplasmic reticulum; sp : intercell space (from Van Impe, 1985).

The length, 1 , of any segment of ontogenetic trajectories, i.e. the distance between two successive stases, may be estimated in the same way. The sum of all segments constituting a trajectory gives its total length, L. The 1/L ratio estimates the contribution of a stase to the trajectory.

\section{RESULTS}

\section{Observation of the egg}

According to Dittrich's publications, the intermediate lamella, formerly named intermediate membrane (Dittrich and Streibert, 1969), appeared about two hours after deposition of the egg and has nothing to do with an embryonic wrapping of cellular origin since the first cleavage occurs only after 2.5 hours (Dittrich and Streibert, 1969). It consisted of layers of protein (chitin) fibrils (Dittrich, 1971). About 44 hours after deposition, perforation organs, first called embryonic stigmata, began to de- velop (Dittrich and Streibert, 1969) while micropillars extended over a special zone of the intermediate lamella (Dittrich, 1971). Perforation organs, described in detail by Dittrich (1971), were birefringent and nothing but specialized setae (Grandjean, 1948). 48 hours after deposition, the respiratory apparatus composed of the perforation cones associated to the zone covered by micropillars was fully formed and perforation of the egg shell by the cones occurred after 68 hours. Some $44 \%$ of the eggs hatched after 76 hours (Dittrich, 1971). After hatching, the intermediate lamella with the perforation cones remained within the egg shell.

If multiple protelattosis occurred in spider mites, two apoderms should coexist within the egg, one belonging to the prelarva and a second belonging to the larva. Tetranychus urticae has transparent eggs, $150 \mu \mathrm{m}$ in size, which allow observation of the complete development under the microscope (Grbić et al. 2007a). No multiple calytostases were detected 
when breaking eggs near hatching and no element from Dittrich's publications and from recent studies (Grbić et al., 2007; Khila and Grbić, 2007) allows concluding to their existence.

\section{Intervening calyptostase}

The observation of pharate individuals at stase $S_{2}$, $S_{3}$ and $S_{4}$ gave the same results: there was no $\mathrm{Cu}-$ ticular structure visible between the external cuticle, the future exuvia, and that of the stase ready to emerge, in light microcopy as well as in TEM (Fig. 3). If there was an intervening calyptostase, a calyptostatic apoderm should be observed between these two cuticular layers.

\section{Comparative chaetotaxy}

A first approach consists in comparing the chaetotaxy of leg segments. As noted by Lindquist (1985), the ontogenetic pattern of trochanters affords a ready distinction between immatures and the socalled adults of spider mites since trochanteral IV appears only in the last stase (Table 2). If we compare it to that of Tuckerellidae, two hypotheses are possible. Either the penultimate stase of Tetranychidae, $S_{3}$, is a deutonymph, or it is a tritonymph. Under hypothesis 1, the trochanteral formula of the so-called tetranychid deutonymph is much richer -more plesiomorphic- than in Tuckerellidae. Hypothesis 1 is in contradistinction to Lindquist's (1985) conclusion that the basic pattern of trochanters in Tetranychidae is derived or apomorphic- compared to that of Tenuipalp-

TABLE 2: Ontogenetic pattern of trochanters in Tuckerellidae and Tetranychidae with distances (d) between homologous stases under hypotheses $\mathrm{H}_{\mathrm{m}}$ (multiple protelattosis) and $\mathrm{H}_{\mathrm{p}}$ (paedogenesis). Distances are measured using the Manhattan metric.

\begin{tabular}{|c|c|c|c|c|c|}
\hline \multicolumn{2}{|c|}{ Tuckerellidae } & \multicolumn{2}{|c|}{ Tetranychidae } & \multicolumn{2}{|c|}{ Distances } \\
\hline Stase & Formula & Stase & Formula & $\mathrm{H}_{\mathrm{m}}$ & $\mathrm{H}_{\mathrm{p}}$ \\
\hline$\left(\mathrm{A}_{5}\right) \mathrm{Ad}$ & $(1-1-2-1)$ & $\mathrm{S}_{4}$ & $(1-1-1-1)$ & $\mathrm{d}\left(\mathrm{Ad}-\mathrm{S}_{4}\right) 1$ & $\mathrm{~d}\left(\mathrm{TN}^{-\mathrm{S}_{4}}\right) 1$ \\
\hline$\left(\mathrm{A}_{4}\right) \mathrm{TN}$ & $(1-1-2-1)$ & $\mathrm{S}_{3}$ & $(1-1-1-0)$ & $\mathrm{d}\left(\mathrm{TN}-\mathrm{S}_{3}\right) 2$ & $\mathrm{~d}\left(\mathrm{DN}-\mathrm{S}_{3}\right) 2$ \\
\hline$\left(\mathrm{A}_{3}\right) \mathrm{DN}$ & $(0-0-1-0)$ & $\mathrm{S}_{2}$ & $(0-0-0-0)$ & $\mathrm{d}\left(\mathrm{DN}-\mathrm{S}_{2}\right) 1$ & $\mathrm{~d}\left(\mathrm{PN}^{-\mathrm{S}_{2}}\right) 1$ \\
\hline$\left(\mathrm{A}_{2}\right) \mathrm{PN}$ & $(0-0-1-0)$ & $\mathrm{S}_{1}$ & $(0-0-0)$ & $\mathrm{d}\left(\mathrm{PN}-\mathrm{S}_{1}\right) 1$ & $\mathrm{~d}\left(\mathrm{La}-\mathrm{S}_{1}\right) 0$ \\
\hline$\left(\mathrm{A}_{1}\right) \mathrm{La}$ & $(0-0-0)$ & & & $\sum=5$ & $\sum=4$ \\
\hline
\end{tabular}

Stase abbreviation as in Fig. 1.

TABLE 3: Mean distance between homologous stases, $d$, under different hypotheses. Calculations are detailed for each leg segment and each set of setae.

\begin{tabular}{lccc}
\hline & $\mathrm{H}_{\mathrm{m}}$ & $\mathrm{H}_{\mathrm{p}}$ & $\mathrm{H}_{\mathrm{o}}$ \\
\hline Trochanters $\left(^{*}\right)$ & 5 & 4 & 4 \\
Femora & 19 & 15 & 15 \\
Genua & 16 & 18 & 18 \\
Tibiae & 13 & 13 & 13 \\
Tarsi & 28 & 22 & 22 \\
Epimera & 14 & 8 & 8 \\
Genitals + aggenitals & 7 & 1 & 3 \\
\hline \multicolumn{1}{c}{$\quad$ Mean distance $(d)$} & 93 & 74 & 76 \\
\hline
\end{tabular}

$\left({ }^{*}\right)$ See details in Table 1. 


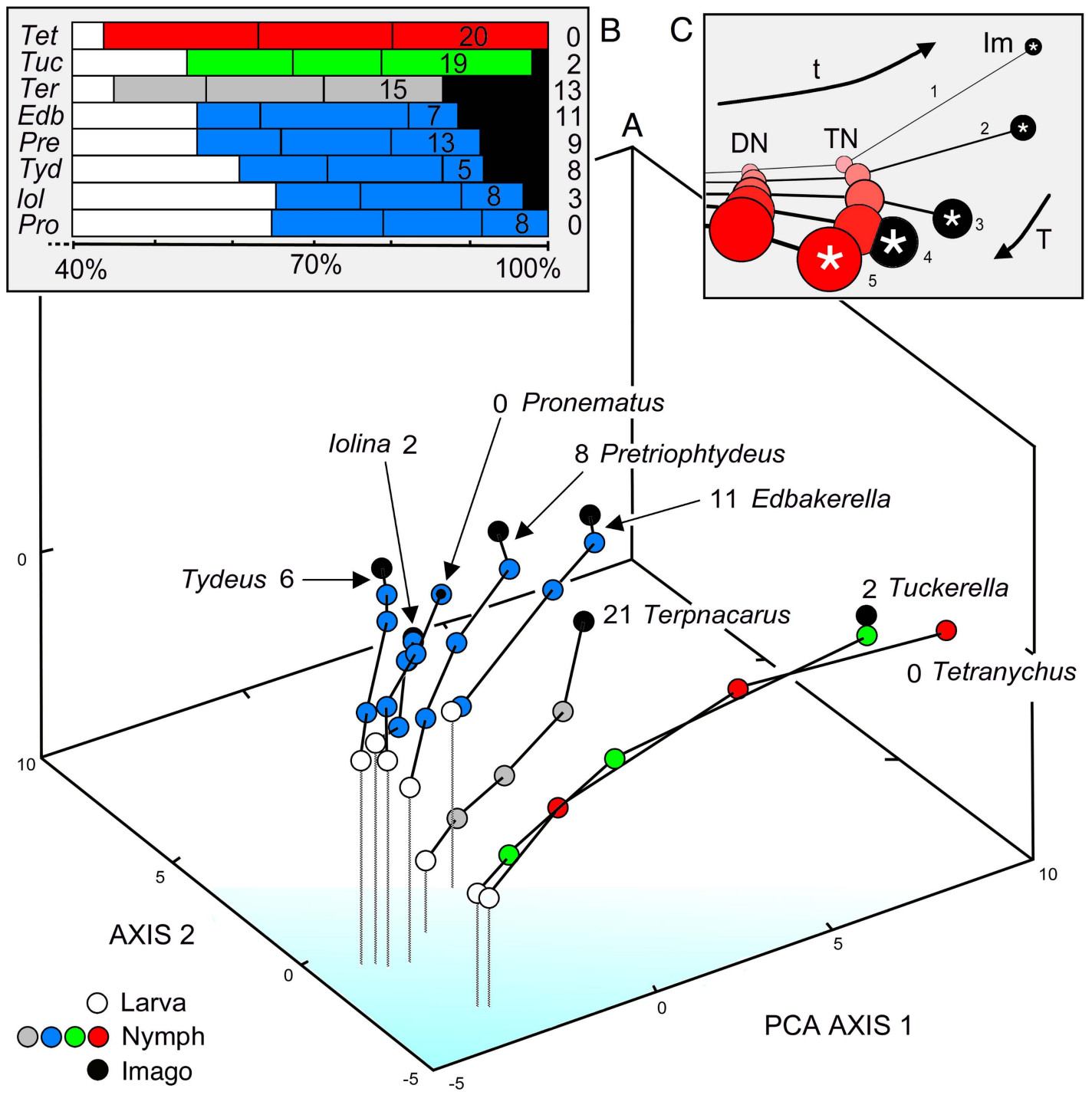

FIGURE 4: Ontogenetic trajectory of Tetranychus and Tuckerella compared to that of Terpnacarus bouvieri (Endeostigmata) and some tydeoid genera. The length of the last segment, i.e. the distance between the imago and the tritonymph, is indicated for each taxon (The length is not necessarily well appreciated on the drawing due to the perspective and use of PCA). In the case of Pronematus, both points representing the imago and tritonymph coincide (dotted circle). Insert B illustrates the contribution (in \%) of each stase to the trajectories; the imago contribution is given at the right; that of the tritonymph, within the corresponding block. Taxa are identified by the first three letters. Insert $C$ schematizes the progenesis in spider mites, with neoteny (steps 1 to 4 ) resulting from the shortening of the imago contribution and progenesis (step 4 to 5) when reproduction is taken over by the tritonymph. t: ontogenetic time; T: phylogenetic time, *: adulthood (reproduction). Other abbreviations as in Fig. 1. 
idae and Tuckerellidae. Under hypothesis 2, trochanteral chaetotaxy in Tetranychidae is derived -apomorphic- at all levels of ontogeny and ontogenies of both families, Tetranychidae and Tuckerellidae, follow parallel trajectories.

To complete this comparative approach of trochanters, the distance, $d$, between the chaetotaxy of homologous stases may be estimated under either hypotheses, $\mathrm{H}_{m}$ and $\mathrm{H}_{\mathrm{p}}$ (Table 3). If we sum these distances for each family, the total is smaller under hypothesis $\mathrm{H}_{\mathrm{p}}$ than under hypothesis $\mathrm{H}_{\mathrm{m}}$. In other words, the ontogenetic trajectory of spider mites, plotted in a 4-dimensional space describing the chaetotaxy of trochanters, is closer to that of Tuckerellidae if we suppose that $S_{1}$ is a larva and $S_{4}$ a tritonymph.

This approach may be repeated for all leg segments as well as for the epimeral and genital chaetotaxy. Ontogenetic trajectories are then plotted into a 27-dimensional space as explained previously (Fig. 4 ). The mean distance estimated between homologous stases is again smaller under hypotheses $\mathrm{H}_{\mathrm{p}}$ (progenesis) than under hypothesis $\mathrm{H}_{\mathrm{m}}$ (multiple prelattosis). This conclusion holds whatever the leg segment studied, but the genua and tibiae (Table 3 ). The mean distance estimated between homologous stases may be estimated again under hypotheses $\mathrm{H}_{0}$ (traditional interpretation) and is slightly longer than under $\mathrm{H}_{\mathrm{m}}$ (Table 3).

\section{DISCUSSION}

\section{The prelarva is a calyptostase}

The morphology of the so-called intermediate lamella equipped with perforation cones recalls the prelarval apoderm observed in many mites and in most insects where the perforation cones are usually called egg-bursters.

Dittrich (in litteris) replied that the prelarva "is nothing but one phase of the embryonic development" and argued that "the perforation organs do belong to the egg and are specific adaptation to his situation concerning water-stress and the necessity of gas-exchange". Far from negating the existence of a prelarva, such adaptations are indicative of the occurrence of a calyptostase. Indeed, the respiratory function assumed by the perforation cones in association with micropillars is detailed by Van Impe (1983, 1985). Respiration through special organs is the first function assigned due to a prelarva that is supposed to be "inactive". That all prelarvae equipped with perforation cones respire this way remains to be explored.

This respiratory function has also been reported in insect calyptostases. For instance, the hemipupa of Cecidomyidae (Diptera), a calyptostase ensheathed in the larva, is equipped with complex spiracles consisting of a truncate cone surmounted by a ring of apertures, each of them surrounded by a pair of radial lip-like ridges. Arising from the cones there are several very stout spines which burst the larval integument covering the hemipupa (Fig. 18 in Wyatt, 1963). Analogies between the two calyptostases, the hemipupa of Cecidomyidae and the prelarva of Tetranychidae, are straightforward: in both cases, cones perforate the outer envelope while the radial ridges in cecidomyids assume the same role as micropillars in spider mites, allowing air access and circulation. The intermediate lamella of Tetranychus is thus, morphologically and functionally, the apoderm of a calyptostatic prelarva. This first step of the post-embryonic development is inactive and disregarded in most studies, even in laboratory conditions (e.g. Baker and Wharton, 1952; Grbić et al., 2007; Khila and Grbić, 2007). Protelattosis, i.e. the occurrence of an inhibited state at the beginning of ontogeny, is widespread in mites. Nearly all prelarvae are calyptostatic; in a few cases, they are elattostasic.

\section{Hypothesis $\mathrm{H}_{\mathrm{m}}$ : multiple protelattosis}

Multiple protelattosis, i.e. the occurrence of several elatto- or calyptostases at the beginning of ontogeny, is common in spiders, with two to four inhibited stases (André and Jocqué, 1986), and in pseudoscorptions, with two to three inhibited stases (Grandjean, 1938a; André and Jocqué, 1986). Generally speaking, the number of successive calyptostases in Arachnida tends to increase from primitive to more evolved taxa. The same trend is observed in insects. A priori, multiple protelattosis 
was thus an attractive hypothesis to explain the peculiarity of ontogeny in spider mites. However, neither the study of the eggs, nor the comparative analysis of chaetotaxy does support this hypothesis. Multiple protelattosis, hypothesis $\mathrm{H}_{\mathrm{m}}$, is thus rejected.

\section{Hypothesis $\mathrm{H}_{\mathrm{i}}$ : intervening calyptostase or metelattosis}

Metelattosis is also common in mites. So far, it has been possible to detect intervening calyptostases even in ontogenies that comprise multiple calyptostases. This is the case of speleognathin Ereynetidae: the three nymphs are all calyptostasic and remain ensheathed in the imago (Fain, 1972 - Fig. 1I). Several intervening calyptostases are also known to occur in the ontogeny of Hypoderidae (the larva, proto-, and tritonymph) (Fain and Bafort, 1967; Fain, 1967) and Erythraeidae (the proto- and the tritonymph) (Grandjean, 1957, 1959). These calyptostases were recognized either through the presence of an apoderm or pharynx detected in light microscopy. In Tetranychidae, no apoderm indicating the existence of an intervening calyptostase was detected. Van lmpe (1985) and André (1988) hypothetized that the protonymph might be calyptostasic since the first nymph of Tetranychidae does not present the denudation of leg IV typical of protonymphs. Their hypothesis does not hold as there is no intervening calyptostase -no metelattosis sensu Hammen $(1975,1980)-$ in the course of ontogeny in Tetranychidae. Hypothesis $\mathrm{H}_{\mathrm{i}}$ is thus rejected.

\section{Hypothesis $\mathrm{H}_{\mathrm{o}}$ vs $\mathrm{H}_{\mathrm{p}}$}

The comparative study of chaetotaxy in Tuckerellidae and Tetranychidae suggests that the first active stase of spider mites is a larva followed by a protonymph. However, we do not yet know the real identity of the last active stase. Provided that hypotheses $\mathrm{H}_{\mathrm{m}}$ and $\mathrm{H}_{\mathrm{i}}$ have been rejected, both hypotheses $\mathrm{H}_{\mathrm{o}}$ and $\mathrm{H}_{\mathrm{p}}$ still hold. In the latter case, the oldest stase in the ontogeny of spider mites is a paedogenetic tritonymph (Fig. 1H); in the former, it is an imago (Fig. 1B). In Tuckerellidae, the leg chaetotaxy of the tritonymph is identical to that of the imago. The only difference in the chaetotaxy of the last two stases concerns the genital area: La (0) $\mathrm{PN}(0-1) \mathrm{DN}(0,2) \mathrm{TN}(0,4)$ Ad $(0,2,4)$. A comparison with Tetranychidae, with genital formulae $\mathrm{La}$ (0) $\operatorname{PN}(0,1) \mathrm{DN}(0,2) \mathrm{S} 4(0,3)$, reveals that the genital chaetotaxy of the last tetranychid stase is closer to that of the tritonymph than that of the imago. This argument is counterbalanced by the presence of male solenidia in the last stase of Tetranychidae, which recalls those found in male Tuckerellidae. The argument is also weakened by the presence of similar formulae in the imago of other families (e.g. in Pronematinae, lolinidae...).

The quantitative method used to test $\mathrm{H}_{\mathrm{o}}$ vs $\mathrm{H}_{\mathrm{p}}$ meets the same problem since the chaetotaxy of the two last stases in Tuckerellidae differs only in the genital formulae. The mean distances between two homologous stases vary little depending on the hypothesis, $\mathrm{H}_{\mathrm{o}}$ vs $\mathrm{H}_{\mathrm{p}}$ (Table 3). There is a small advantage in favor of $H_{p}$, which results from the differences in genital chaetotaxy explained in the previous paragraph.

A last approach consists in comparing the Tetranychoidae to another super-family the ontogenetic patterns of which are well known (Fig. 4). The similarity between the tuckerellid tritonymph and imago (in other words, the short length of the last segment of the ontogenetic trajectory) resembles that found in some Tydeoidea: the more evolved is the genus, the least is the contribution of the imago to the trajectory. In other words, the length of the last segment of the ontogenetic trajectories tends to get smaller and smaller until the imago coincides to the tritonymph as in Pronematus (step 4 in Fig. 4 Insert C). The same trend is observed in the ontogenetic trajectory of Tetranychoidea. In Tuckerella, the imago contribution to the trajectory is only $2 \%$ and becomes null in Tetranychus (Fig. 4B). The situation in Tetranychus is similar to that of Pronematus, except that the imago is missing. Indeed, if we suppose that the last stase of Tetranychus is a tritonymph, its contribution is similar to that of the tritonymph in Tuckerella (20\% vs. $19 \%$ ) in the same way the contribution of the tritonymph of Pronematus is similar to that of lolina ( $8 \%$ in both taxa) (Fig. 4, Insert B).

Supposing that the last stase of Tetranychus is 
an imago meets two other objections. The first results from the comparative study of ontogenetic trajectories. Indeed, the last stase of Tetranychus contributes to $20 \%$ of the length of the trajectory; such a high contribution has never been observed in any imaginal stase. A second objection is raised by the implicit absence of the tritonymph. Such an absence in Tetranychus seems little realistic when compared to endoparasitic species. Indeed, even endoparasitic species with a sophisticated ontogeny as that observed in Speleognathinae, have kept all the nymphs: all three are reduced to calyptostases. This was interpreted as an indicator of developmental constraints by André (1992). Hypothesis $H_{o}$ is thus rejected in favor of hypothesis $\mathrm{H}_{\mathrm{p}}$.

\section{Paedogenesis in Tetranychus and actinotrichid mites}

Identifying the last stase in Tetranychus as a tritonymph implies that it is paedogenetic. Is this acceptable? Paedogenesis in actinotrichid mites has been reported in various groups, in Podapolipidae by Volkonsky (1940), Pyemotidae by Rack (1972), Tenuipalpidae by Baker (1979) and Cheyletidae by Atyeo et al. (1984). The penultimate case is of special interest as Tenuipalpidae are part of Tetranychoidea. The missing link is however provided by Ochoa (1989) who reported paedogenetic tritonymphs coexisting with imaginal females in Tuckerella knorri. This particular ontogeny is summarized in Fig. $1 \mathrm{G}$ and links ontogenies A (usually observed in Tuckerellidae, Beard and Walter, 2005) and $H$ (that of T. urticae). A second intermediate case is provided by Tuckerella saetula and $T$. cf. pavoniformis in which the male directly emerges from the deutonymph (Beard and Ochoa, 2010).

In the context of the stase theory, Hammen (1975) called alassostasy the variations in the number of stases and the process of loosing a stase during the ontogeny was named meristasy by André (1988). The ontogeny in Tetranychidae is thus characterized by the meristasy of the imaginal stase.

\section{Adult state, adult instar and adult stase}

The current terminology of post-embryonic development is confusing and bewildering (Breene, 2003) as it pertains to three approaches. The first approach is related to form, state and, sometimes, function. A mite larva is defined or described by the presence of six legs. Adults are defined by genitalia and their function is reproduction.

A second and traditional framework for the description of arthropod development takes the moltto-molt interval as the fundamental unit of periodization (Minelli et al., 2006). In some cases, this number is variable and no homology between instars is possible, the example of Argasidae is illustrative. The instar terminology refers to the same words as the form approach: larva and adult.

A last and third approach emphasized by Grandjean (1938a, 1970) and André $(1988,1989)$ is related to stases. Stases are based on idionymy, it is thus possible to homologize them. Again, the same words are used to define ontogenetic levels, larva and adults.

As a result, some confusion revolves around the use of the term "adult". If by tradition the $6^{\text {th }}$ level of ontogeny is named the adult -or more precisely the adult stase, we have to admit that the adult state -or adulthood-is likely to occur at an earlier level. The confusion is not new and some entomologists prefer to use the term "imago" to refer to the last step of the usual ontogeny; unfortunately, this usage is not widely accepted. We thus propose to rename the $6^{\text {th }}$ level of mite ontogeny and to call it the imago (Im). This designation of the final step in ontogeny is in agreement with dictionaries (Séguy, 1967; Oxford Dictionaries, 2010). The text of this publication has been revised accordingly as well as figures.

\section{Heterochrony and development in arachnids}

Three evolutionary changes involved in the ontogeny of mites are illustrated in Fig. 1H-I-J. The first change concerns stases that are calyptostasic, even in parasitic species. Apparently, there are just two active instars, the larva and the imago in ereynetid Speleognathinae (Fig. 1I). There is however neither a shortening of ontogeny when stases are considered, nor an "omission" as misunderstood by Matsuda (1979). A second case concerns a real missing stase: there is no deutonymph in some 
Astigmata, even when permanent rearing is available. The mite that follows the protonymph in ontogeny is homologized with a real tritonymph (Fig. $1 \mathrm{JJ)}$. Last, T. urticae shows a third change, there is a real truncation of the post-embryonic development (Fig. 1H). The number of active instars is the same as in the second case but the reduction occurs at another level of development.

As explained in a former section, paedogenesis in actinotrichid mites is common. The paedogenesis described in other actinotrichid mites is however different from what happens in Tetranychidae. In other mites, eggs or larvae were observed in the idiosoma of immature stases. As the latter lack a genital orifice, the former are supposed to escape by rupture of the integument of the maternal idiosoma (Evans, 1992) as is the case for some insects as the genus Miastor (Diptera, Cecidomyidae). In insects, these paedogenetic females reproduce most often by parthenogenesis, ovaries proliferate and give rise to haemocoelous embryos that develop into young larvae feeding on the maternal tissues. This method of reproduction is fundamentally different from the usual process of laying eggs through the oviducts observed in Tetranychidae tritonymph but this process might precede and indicate a truncation of development. The use of this term prompts another comment. Paedogenesis is part of the heterochrony conceived as any change in rate or timing of ontogeny. Gould (1977) gives a historical overwiew of the origin and development of this terminology. In Tetranychidae, there is a nymphal reproduction via precocious reproductive development. This peculiarity does not obey the original definition of paedogenesis, a term coined by Baer (1866; cited in Gould, 1977) who published only a few minor, mostly trivial papers on insects (Groeben, 1993). Baer restricted his definition to cases of parthenogenesis in insect larvae structurally unable to copulate. Hamann (1891; cited in Gould, 1977) extended Baer's term to include all precocious development. Tetranychid development conforms to Hamman's meaning and also obeys the definition of progenesis, a term coined by Giard (1887; cited in Gould, 1977) to designate accelerated reproductive development. This term is even used by Gould (1977) to describe the development of the mite Siteroptes graminum. Progenesis in trematodes, another taxon with molts, encompasses all cases where a larval stage produces viable eggs (Lefebvre and Poulin, 2005).

Another distinction is often made by entomologists. They speak of prothetely when the adult develops too "early" (the quotes are by Gould, 1977), perhaps at a precocious molt. In this context, prothetely is opposed to metathetely. "When an insect becomes a neotenous adult after undergoing a normal or more than normal number of molts, the condition is metathetely; whereas it becomes a neotenous adult after undergoing less than the normal number of molts, the condition is prothetely" (Matsuda, 1979: 139, definition recalled in Pearson, 2004: 73). This approach is based on the number of molts and not on development levels.

Pearson (2004) laments the confusion surrounding heterochrony. This is still true. If this terminology applies to mite development, it is little relevant to the stase approach. There is no reference to Grandjean's publications in the references listed by Gould (1977).

\section{CONCLUSIONS}

All elements (study of the chaetotaxy, comparison with related families (Tuckerellidae), comparison with other mites such as the Tydeoidea) lead to the same conclusion. The development of Tetranychus urticae comprises five stases (among which four are active) and the tritonymph has the reproduction in charge. The post-embryonic development may be summarized this way: prelarva (calyptostase), larva (six-legged stase), protonymph (eight-legged stase), deutonymph (eight-legged stase), tritonymph (with paedogenesis, i.e. precocious development of sexual maturity). Tetranychidae are evolved mites with typical colonizing and 'opportunistic' features (Lebrun et al., 1991). The occurrence of the imaginal meristasy resulting from paedomorphosis is not surprising in such a taxon. Within the Prostigmata, there is marked trends towards a reduction in chaetotaxy, especially in imagines and secondarily in tritonymphs (as opposed to taxa characterized by 
neotrichy), and towards a shortening of the ontogenetic trajectories. The neotenous features (in terms of arrest of development of the chaetotaxy) have become increasingly pronounced in Prostigmata and seem to indicate a phylogenetic neoteny. This trend contrasts with that observed in Oribatida in which the imago has become heteromorphic in higher taxa (Euoribatida).

Tetranychidae offer an illustrative example of the passage from an ontogeny with five active stases to another with only four, or, if we consider also the calyptostases, from an ontogeny with six stases to another with five. The meristasy of 5 and $6^{\text {th }}$ levels probably applies also to Eriophyidae with two active stases following a calyptostatic prelarva described by Shevchenko (1961).

It may be of interest to recall that the fundamental number of stases is six in actinotrichid mites, i.e. the same number as in Pseudoscorpions and Ricinulei. This has even been an argument to combine the Acari and the Ricinulei under the name Acaromorpha (see the review by Weygoldt, 1998). Among Anactinotrichida, Opiliocariformes and maybe Holothyrida have also six stases. Mesostigmata have an ontogeny with only four active stases. That they have followed the same process as Tetranychidae in reducing the number of stases remains to be explored. Meristasy of the terminal stase is also known in Peudoscorpions in which the tritonymphal stase is adult (Judson, pers. comm.).

\section{ACKNOWLEDGEMENTS}

The use of TEM was possible thanks to $\mathrm{Cl}$. Remacle. Preliminary drafts of this publication were read and criticized by R. Jocqué, G. Le Goff and D. van den Spiegel.

\section{REFERENCES}

André H.M. 1980 - A generic revision of the family Tydeidae (Acari: Tydeidae). IV. Generic descriptions, keys and conclusions - Bull. Annls Soc. r. belge Ent., 116: 103-130, 139-168.

André H.M. 1984 - Redefinition of the Iolinidae (Acari: Actinedida), with a discussion of their familial and superfamilial status. In: Griffiths D.A. and Bowman C.E.
(Eds), Acarology VI, vol.1 - Ellis Horwool Publishers, Chichester, UK, pp. 180-185.

André H.M. 1988 - Age-dependent evolution: from theory to practice - In: Humphries C.J. (Ed.), Ontogeny and systematics. Columbia University Press, New York, USA, pp. 137-187.

André H.M. 1989 - The concept of stase - In: André H.M., Lions J.-C. (Eds) L'ontogenèse et le concept de stase chez les arthropodes. AGAR Publishers, Wavre, pp. 3-16.

André H.M. 1992 - Calyptostases as indicators of developmental constraints in mites and other arthropods Acarologia, 33: 223-231.

André H.M. 2005 - In search of the true Tydeus (Acari: Tydeidae) - J. nat. Hist., 39: 975-1001. doi:10.1080/00222930400002838

André H.M., Fain A. 1991 - Ontogeny in the Tydeoidea (Ereynetidae, Tydeidae and Iolinidae) - In: Dusbábek, F. and Bukva, V. (eds.), Modern Acarology, (Vol. 2), Academia, Praha and SPB Academic Publ., The Hague, pp. 297-300.

André H.M., Jocqué R. 1986 - Definition of stases in spiders and other arachnids - Mém. Soc. r. belge Ent., 33: 1-14.

André H.M., Remacle Cl. 1984 - Comparative and functional morphology of the gnathosoma of Tetranychus urticae (Acari: Tetranychidae) - Acarologia, 25: 179190.

Atyeo W.T., Kethley J.B., Pérez T.M. 1984 - Paedomorphosis in Metacheyletia (Acari: Cheyletidae), with the description of new species - J. med. Entomol., 21: 125-131.

Baer, K.E. von. 1866 - Über Prof. Nic. Wagner's Endeckung von Larven, die sich fortplanzen, Herrn Garren's verwandte und ergänzende Beobachtung und über die Pädogenesis überhaupt - Bull. Acad. Imp. Sci. St Petersbourg, 9: 63-137.

Baker E.W. 1979 - A note on paedogenesis in Brevipalpus sp. (Acari: Tenuipalpidae), the first such record for a mite - Int. J. Acarol., 5: 355-356. doi:10.1080/01647957908683181

Baker E.W., Wharton, G.W. 1952 - An introduction to acarology - The Macmillan Company, New York, USA.

Beard J., Ochoa, R. 2010 - Ontogenetic modification in the Tuckerellidae (Acari: Tetranychoidea) - Int. J. Acarol., 36: 169-173. doi:10.1080/01647950903555459

Beard J.J., Walter D.E. 2005 - A new Tuckerella (Prostigmata: Tetranychoidea; Tuckerellidae) from Australia with description of all stages and a discussion of the tritonymphal stage - Acarologia, 45: 49-60.

Breene, III, R. G. 2003 - Arachnid developmental stages: Current terminology - American Tarantula Society, Forum Magazine, 12(3): 82-85. 
Coineau Y. 1974 —Éléments pour une monographie morphologique, écologique et biologique des Caeculidae (Acariens) - Mém. Mus. nat. Hist. nat. Paris, 81: 1-300, 24 pI.

Dittrich V. 1968 - Die Embryonalentwicklung von Tetranychus urticae Koch in der Auflichtmikroskopie Z. angew. Ent., 61: 142-153.

Dittrich V. 1971 - Electron-microscopic studies of the respiratory mechanism of spider mite eggs - Ann. ent. Soc. Amer., 64: 1134-1143.

Dittrich V., Streibert P. 1968 - The respiratory mechanism of spider mite eggs - Z. angew. Ent., 63: 200-211.

Evans G.O. 1991 — Principles of Acarology - CAB International, Willingford, UK.

Fain A. 1967 - Les hypopes parasites des tissus cellulaires des oiseaux (Hypodectidae, Sarcoptiformes) Bull. Inst. r. Sci. natur. Belgique, 43: 1139.

Fain A. 1972 - Développement postembyronnaire chez les Acariens de la sous-famille Speleognathinae (Ereynetinae: Trombidiformes) - Acarologia, 13: 607614.

Fain A., Bafort J. 1967 - Cycle évolutif et morphologie de Hypodectes (Hypodectoides) propus (Nitzsh.) acarien nidicole à deutonymphe parasite tissulaire des pigeons — Bull. Acad. roy. Sci. Belg., 53: 501-533.

Fink T.J. 1983 - Further note on the use of the terms instar, stadium, and stage - Ann. Entomol. Soc. Am., $76: 316-318$.

Gould S.J. 1977 - Ontogeny and Phylogeny - Cambridge, Massachusetts: The Belknap Press of Harvard University Press, USA.

Grandjean F. 1938a - Sur l'ontogénie des Acariens C. R. Acad. Sci. Paris, 206D: 146-150 [43] (Numbers between square brackets designate the identification number of Grandjean's reprints as they were published in 7 volumes by L. van der Hammen).

Grandjean F. 1938b - Au sujet de la néoténie chez Ies Acariens - C. R. Acad. Sci. Paris, 207D: 1347-1351 [54].

Grandjean F. 1939 - Quelques genres d'acariens appartenant au groupe des Endeostigmata - Ann. Sci. nat. Zool. (sér. 2), 11: 1-122 [60].

Grandjean F. 1941 - La chaetotaxie comparée des pattes chez les Oribates ( $1^{\mathrm{e}}$ série $)$ - Bull. Soc. ent. France, 46: 33-50 [70].

Grandjean F. 1946 - La signification évolutive de quelques caractères des Acariens ( $1^{\text {re }}$ série) - Bull. biol. France Belg., 79: 297-325 [99].

Grandjean F. 1948 - Quelques caractères des Tétranyques - Bull. Mus. nat. Hist. nat. (2), 20: 517-524 [117].
Grandjean F. 1957 — L'évolution selon I'âge — Archs Sci. Genève, 10: 477-526 [184].

Grandjean F. 1959 - Les stases du développernent ontogénétique chez Balaustium florale (Acarien Erythroide). $2^{\mathrm{e}}$ partie - Ann. Soc. ent. France, 128: 159179 [198].

Grandjean F. 1970 - Stase. Actinopiline. Rappel de ma classification des Acariens en trois groupes majeurs Acarologia, 11: 796-827 [236].

Giard A. 1887 - La castration parasitaire et son influence sur les caractères extérieurs du sexe mâle chez les crustacés décapodes - Bull. Sci. Département du Nord, 18: 1-28.

Grbić M., Khila A., Lee K.-Z., Bjelica A., Grbić V., Whistlecraft J., Verdon L., Navajas M., Nagy L. 2007 — Mity model: Tetranychus urticae, a candidate for chelicerate model organism - BioEssays, 29: 489-496.

Groeben C. 1993 - Karl Ernst von Baer [1792-1876], Anton Dohrn [1840-1909]: Correspondence - Transactions of the American Philosophical Society, 83(3): 1156. doi: $10.2307 / 1006493$

Hamann, O. 1891 - Monographie der Acanthocephalen (Echinorhynchen) - Jena. Z. Naturwissenschaft, 25 (n.s. 17): 113-231.

Hammen, L. van der. 1975 — L'évolution des Acariens et les modèles de l'évolution des Arachnides - Acarologia, 15 : 377-381.

Hammen, L. van der. 1980 - Glossary of acarological terms. I. General terminology - W. Junk, The Hague, The Netherlands, pp. 244.

Helle W., Sabelis, M.W. 1985 - Spider mites. Their biology, natural enemies and control. Vol. 1A - Elsevier, Amsterdam, The Netherlands, pp. 405.

Hinton H.E. 1971 - Some neglected phases in metamorphosis - Proc. R. Soc. Lond., 35C: 55-64.

Hinton H.E. 1973 - Neglected phases in metamorphosis: a reply to V. B. Wiggelsworth - J. Ent., 48A: 57-68.

Hinton H.E. 1976 - Notes on neglected phases in metamorphosis, and a reply to J. M. Whitten - Ann. ent. Soc. Amer., 69: 559-566.

Khila A., Grbić M. 2007 - Gene silencing in the spider mite Tetranychus urticae: dsRNA and siRNA parental silencing of the Distal-less gene - Dev. Genes Evol., 217: 241-251. doi:10.1007/s00427-007-0132-9

Lebrun Ph., Van Impe G., de Saint-Georges-Gridelet D., Wauthy G., André H.M. 1991 - The life strategies of mites - In: Schuster R. and Murphy P.W. (Eds.), The Acari. Reproduction, development and life-history strategies. Chapman and Hall, London, UK, pp. 3-22.

Lefebvre, F., Poulin, R. 2005 - Progenesis in digenean trematodes: a taxonomic and synthetic overview of species reproducing in their second intermediate hosts — Parasitology, 130: 587-605 
Lindquist E.E. 1985 — External anatomy — In: Helle W. and Sabelis M.W. (Eds) Spider mites. Their biology, natural enemies and control. Elsevier Science, Amsterdam, pp. 3-28.

Matsuda R. 1979 - Abnormal metamorphosis and arthropod evolution - In: Gupta A.P. (Ed.) Arthropod Phylogeny. New York: Van Nostrand, USA, pp. 134-256.

Minelli, A., Brena, C., Deflorian, G., Maruzzo, D., Fusco, G. 2006 - From embryo to adult-beyond the conventional periodization of arthropod development Dev. Genes Evol., 216: 373-383. doi:10.1007/s00427006-0075-6

Ochoa R. 1989 - A note on paedogenesis in Tetranychoidea - Int. J. Acarol., 15: 117-118. doi:10.1080/01647958908683834

Oxford Dictionaries. 2010 - imago — Oxford University Press, Oxford, UK.

Pearson R.D. 2004 - The determined embryo: homeodynamics, hormones, and heredity - In: Hall B.K., Pearson R.G., Muller G.B. (Eds). Environment, Development, and Evolution: Toward a Synthesis. Cambridge, MA: MIT Press, USA, pp. 67-84.

Quiros-Gonzales M.I., Baker E.W. 1984 - Idiosomal and leg chaetotaxy in the Tuckerellidae Baker and Pritchard: Ontogeny and nomenclature - In: Griffiths D.A. and Bowman C.E. (Eds), Acarology VI, vol. 1. Chichester, Ellis Horwood Publishers, UK, pp. 166173.

Rack G. 1972 - Pyemotiden an Gramineen in schwedichen landwirtschaftlichen Betrieben. Ein Beitrag zur Entwicklung von Siteroptes graminum (Reuter, 1900) (Acarina, Pyemotidae) - Zool. Anz. Leipzig, 188: 157-174.

Robaux P., Gutierrez J. 1973 - Les phanères des pattes et des palpes chez deux espèces de Tetranychidae: nomenclature et évolution au cours de l'ontogenèse Acarologia, 15: 616-643.

Séguy E. 1967 - Dictionnaire des termes techniques d'entomologie élémentaire, XLI - Éditions Lechevalier, Paris, France.

Shevchenko V.G. 1961 - Osobennosti postembryonal'nogo razvitiya chetyrekhnogikh kleschei- galloobrazovatelei (Acariformes, Eriophyidae) i nekotorye zamechaniya po sistematike Eriophyes laevis (Nal., 1889) — Zool. Zh., 40: 1143-1158 [in Russian].

Van Impe G. 1983 - Incidences toxicologiques de l'évolution du système respiratoire embryonnaire chez l'acarien tisserand commun, Tetranychus urticae Koch (Acari: Tetranychidae) - Med. Fac. Landbouw. Rijksuniv. Gent, 48: 253-261.

Van Impe G. 1985 - Contribution à la conception de stratégies de contrôle de l'Acarien tisserand commun Tetranychus urticae Koch (Acari: Tetranychidae) - D. Sc. thesis, Université Catholique de Louvain, 382 pp. (2 vol., unpublished).

Volkonsky M. 1940 - Podapolipus diander n. sp. acarien hétérostigmatique parasite du criquet migrateur ( $\mathrm{Lo}^{-}$ custa migratoria L.) - Archives Inst. Pasteur Algérie, 18: 321-340.

Wainstein B.A. 1958 - Chaetom of the Tetranychidae (Acariformes) and the systematics of this family Khetim konechnostei pautinnykh kleshchei (Acariformes, Tetranychidae) I sistema semelstva - Zool. Zh. 37: 1476-1487 [in Russian].

Walter D.E., Krantz G.W. 2009 - Ovoposition and life stages - In: Krantz G.W. and Walter D.E. (Eds), A Manual of Acarology ( $3^{\text {rd }}$ ed.), Texas Tech University Press, USA, pp. 57-63.

Weygoldt, P. 1998 - Evolution and systematics of the Chelicerata - Exp. appl. Acarol., 22: 63-79. doi:10.1023/A:1006037525704

Wyatt I.J. 1963 - Pupal paedogenesis in the Cecidomyiidae (Diptera-II.) - Proc. R. ent. Soc. London, 38A: 136-144.

\section{COPYRIGHT}

(co) EY-Nc-ND André H.M. and Van Impe G. Acarologia is under free license. This open-access article is distributed under the terms of the Creative Commons-BY-NC-ND which permits unrestricted non-commercial use, distribution, and reproduction in any medium, provided the original author and source are credited. 